Bryant University

Bryant Digital Repository

History and Social Sciences Faculty Journal

Articles

History and Social Sciences Faculty

Publications and Research

$12-14-2018$

\title{
The Human Right to Science and Foundational Technologies
}

Andrea Boggio

Bryant University, aboggio@bryant.edu

Calvin W. L. Ho

Follow this and additional works at: https://digitalcommons.bryant.edu/histss_jou

Part of the Other Arts and Humanities Commons

\section{Recommended Citation}

Andrea Boggio, Calvin Ho (2018-12-14). The Human Right to Science and Foundational Technologies. The American Journal of Bioethics 18 (12) : 69-71. https://doi.org/10.1080/15265161.2018.1531173

This Article is brought to you for free and open access by the History and Social Sciences Faculty Publications and Research at Bryant Digital Repository. It has been accepted for inclusion in History and Social Sciences Faculty Journal Articles by an authorized administrator of Bryant Digital Repository. For more information, please contact dcommons@bryant.edu. 


\section{Andrea Boggio \& Calvin W. L. Ho \\ The Human Right to Science and Foundational Technologies}

The American Journal of Bioethics, 18:12, 69- 71 (2018)

Feeney et al. (2018) make a valid argument for restrictions on the exclusivity of foundational technologies such as CRISPR. The issue of balancing intellectual property right with access to scientific and technological advancements is certainly not new. In our commentary, we argue that the human right to science offers a more concrete basis for governments to balance their competing commitments in promoting scientific development on the one hand, and ensuring benefit-sharing on the other, in ways that advance social justice under non-ideal conditions.

\section{The Human Right to Science}

The human right to science is recognized by Article 27 of the Universal Declaration of Human Rights ("Universal Declaration”) and Article 15 of the International Covenant on Economic, Social and Cultural Rights (“Covenant”). The Covenant binds States Parties (i.e., states that have ratified it), whereas the Universal Declaration binds all states since it has achieved customary international law status. As a result, states must "respect, protect, promote, and fulfill” the right to science. To do so, states must refrain from violating or interfering with the enjoyment of a right (respect), take active measures to prevent violation of the right (protect) and to advocate for, encourage, and otherwise support the advancement of the right (promote), and, implement the affirmative measures that are necessary to fully realize the right (fulfill) (Leckie, Gallagher, and Gallagher, 20). To discharge these obligations, state actions must be deliberate, concrete, and as targeted as possible (Committee on Economic. Social and Cultural Rights 1991).

At its core, the human right to science encompasses two distinct but interrelated sets of rights: the right of everyone to benefit from advancements in science and technology and the right to freedom of scientific research (Boggio and Romano 2018). Also, Article 15.2 of the Covenant demands that States Parties take steps "to achieve the full realization of this right ... [including] those necessary for the conservation, the development and the diffusion of science and culture.” Human rights law triggers people's right "to have a legislative and policy framework adopted and implemented which aims at making the benefits of scientific progress available and accessible both through encouraging new scientific discoveries and through removing barriers for existing scientific knowledge to be used for public benefit” (London, Cox, and Coomans 2016).

\section{Right to Science as Policy Justification to (Re-)Calibrate Patent Exclusivity}

The issue of patent protection for foundational technologies implicates primarily the right of everyone to benefit from scientific and technological advancements as codified in Article 15.1.b of the Covenant. This provision speaks to the right to access scientific knowledge, the material results of scientific research and the means to access knowledge and results. As Feeney et al. (2018) explain, overly robust patent protection for foundational technologies may, in fact, limit access to the material benefits of the advancements in science and technology at multiple levels 
and could even stifle scientific progress altogether. In response, they propose a 'non-ideal solution' that is primarily directed at limiting the exclusionary rights of the patentee. In implementation, they argue that limitations should be imposed on certain technical fields (e.g., environment or health) in which patent rights are exercised, on certain types of activity that can be constrained by such rights, and on the exclusivity period. We agree that the proposed response is an important one to consider not only for the reasons that the authors have provided but also because human rights analysis will similarly highlight the obligation of governments to ensure that patent rights do not compromise the capabilities of individuals to live well.

By human rights standards, governments must ensure that intellectual property rights do not preclude access to the material benefits of scientific knowledge or research and development (R\&D). While this issue quickly turns into an empirical question—one that Feeney et al. (2018) acknowledge to be an open one for the contested patent rights over CRISPR - what we want to highlight in this commentary is that human rights law demands a shift in perspective. Intellectual property regimes must be continuously refined, to ensure that everyone has the capability of contributing to, as well as reap the benefits of, scientific innovation and technological advancements.

To this end, intellectual property regimes must incorporate "flexibilities," a term used by Farida Shaheed, Special Rapporteur in the field of cultural rights, in her 2012 report (United Nations 2012). These "flexibilities" are needed to "[r]ecalibrat[e] intellectual property norms that may present a barrier to the right to science and establish[...] greater coherence among them seem to be necessary steps” to ensure that human rights standards are respected (United Nations 2012, 16). It is important to note that "recalibrating" does not mean voiding or disregarding intellectual property rights. Article 15.c of the Covenant provides that authors and inventors are entitled "to benefit from the protection of the moral and material interests resulting from any scientific, literary or artistic production.” Patents are part of this protection. However, the Covenant provides that this protection is not absolute but must be balanced with the other human rights considerations sanctioned by this instrument. The important difference between the right to science approach from that proposed by Feeney et al. (2018) is the responsive dynamism that is implicit in calibrating patent rights, as opposed to the more reactive imposition of limits entailed in the latter.

\section{The Right to Science is action-oriented and advances a more participatory approach to governance}

While justifications for the restrictions proposed by Feeney et al. (2018) are well grounded in social justice, it is less clear how these normative arguments can be translated into policy or governance measures. The right to science, particularly where it is closely aligned with the more established right to health, offers a more concrete basis for governments to balance their competing

commitments in promoting scientific development on the one hand and ensuring benefit-sharing on the other. In addressing health inequalities, for instance, a human rights framework has been developed to identify human rights instruments, as well as mechanisms, by which governments can be held accountable under human rights law (Stronks et al. 2016). 
Applying this human rights framework to R\&D governance in health systems, accountability on the part of governments could include proactively introducing policies that: adopt an inclusive understanding of innovation to develop novel technologies for unmet needs through multiple public- and private-sector partnerships; and promote innovative R\&D models that delink research funding from sales revenue. In addition, governmental responsibility would include monitoring and assessing the overall effects of innovations on health systems for their intended and unintended effects over time and if they help to reduce inequalities (Bigdeli, Peters, and Wagner 2014).

Importantly, the right to science is democratic and participatory in that it empowers individuals through its prescription on everyone an equal opportunity to achieve health and wellness through scientific R\&D. Like the right to health, the right to science provides the basis for legal recourse, which, if successful, can result in tangible changes in the intellectual property regime. We have witnessed this in the context of access to innovative treatments for HIV/AIDS. Human rights (relating to health and science) have mobilized people and supportive institutions to hold governments accountable for addressing inequalities through social movements and market transformation (Kapstein and Busby 2013).

In conclusion, we consider the right to science to complement the approach proposed by Feeney et al. (2018). Patent regimes have been constructed for particular purposes, but without having to completely overhaul what we have to ensure fairer outcomes, it must be supported by individual empowerment, accountability mechanisms and social institutions that the right to science could enable (Ho 2010).

\section{Bibliography}

Bigdeli, Maryam, David H. Peters, and Anita K. Wagner. 2014. Medicines in Health Systems: Advancing access, affordability and appropriate use. Geneva: Alliance for Health Policy and Systems Research and World Health Organization.

Boggio, Andrea, and Cesare P.R. Romano. 2018. "Freedom of research and the right to science: from theory to advocacy." In The Freedom of Scientific Research: Bridging the Gap Between Science and Society, edited by Simona Giordano, 162-175. Manchester: Manchester University Press.

Committee on Economic. Social and Cultural Rights. 1991. General Comment No. 3, The Nature of States Parties' Obligations. UN Doc. E/1991/23, Annex III, para. 2.

Feeney, Oliver, Julian Cockbain, Michael Morrison, Lisa Diependaele, Kristof Van Assche, and Sigrid Sterckx. 2018. "Patenting foundational technologies: Lessons from CRISPR and other core biotechnologies " American Journal of Bioethics [this issue].

Ho, Calvin W. L. . 2010. "Utilitarianism and Patents: Justification and Change." Asian Bioethics Review 2 (3):202-217.

Kapstein, Ethan B., and Joshua W. Busby. 2013. AIDS Drugs For All: Social Movements and Market Transformations. Cambridge.

Leckie, S., A.T. Gallagher, and A. Gallagher. 2006. Economic, Social, and Cultural Rights: A Legal Resource Guide: University of Pennsylvania Press. 
London, Leslie, Helen Cox, and Fons Coomans. 2016. "Multidrug-resistant TB: implementing the right to health through the right to enjoy the benefits of scientific progress." Health and human rights 18 (1):25.

Stronks, Karien, Brigit Toebes, Aart Hendriks, Umar Ikram, and Sridhar Venkatapuram. 2016. Social justice and human rights as a framework for addressing social determinants of health. Final report of the Task group on Equity, Equality and Human Rights.

Copenhagen: World Health Organization.

United Nations. 2012. Report of the Special Rapporteur in the field of cultural rights, Farida Shaheed, 'The right to enjoy the benefits of scientific progress and its applications', presented at the 20th session of the Human Rights Council (14 May 2012)(A/HRC/20/26). 